\title{
EVALUASI PENGEMBANGAN DESA BUDAYA KERTALANGU DENPASAR SEBAGAI DAYA TARIK WISATA
}

\author{
I Made Agus Asta Panca dan I Nyoman Darma Putra \\ Email : agusasta85@gmail.com
}

\begin{abstract}
The Kertalangu Cultural Village, located just north of Sanur beach, was established in 2007 and meant to be an alternative tourist attraction in Denpasar. Initially, this cultural village had developed as planned, but later on it faced a phase of decline. This article evaluates the implementation of Kertalangu Cultural Village development program seen from the aspect of context, input, process and product. Data were collected by interviewing and distributing questionnaires. The total number of respondents was 97, determined using the Slovin formula, with the disproportionate stratified random sampling technique. Data were analyzed by Evaluation Theory, Theory of Sustainable Tourism Development and Tourism Regional Development Theory. The results show that the implementation of Kertalangu Cultural Village development programs is still not running optimally. The constraints that faced are the management is not optimal, the limited budget allocated to the development of tourism potential and the lack of good coordination between the manager and the manager at the Kesiman Kertalangu Village.
\end{abstract}

Keywords: evaluation, Kertalangu cultural village, alternative tourist attraction, Denpasar

\section{Pendahuluan}

Desa Budaya Kertalangu merupakan salah satu daya tarik wisata di Kota Denpasar yang berorientasi pada upaya pelestarian lingkungan dan seni budaya. Desa budaya ini berdiri berdasarkan Surat Keputusan Walikota Nomor 25 Tahun 2008 tentang Penetapan Desa Kesiman Kertalangu Kecamatan Denpasar Timur sebagai Desa Budaya. Sejak diresmikan pada tahun 2007, desa ini tumbuh dan berkembang menjadi salah satu wisata alternatif yang mampu menarik kunjungan wisatawan baik domestik maupun mancanegara. Perlu ditegaskan bahwa 'desa budaya' di sini tidaklah sama dengan 'desa' pada umumnya yang memiliki penduduk, batas, kepemimpinan, tetapi suatu ruang yang diformat sebagai daya tarik wisata dan diberi nama 'desa wisata' atau 'cultural village'. Desa Budaya Kertalangu bukanlah desa dalam pengertian nyata tetapi ruang yang dikonstruksi 
menjadi daya tarik. Desa Budaya Kertalangu terletak di wilayah Desa Kesiman Kertalangu.

Sejak dibentuk, Desa Budaya Kertalangu berkembang dengan baik. Eksistensi Desa Budaya Kertalangu sebagai daya tarik wisata semakin terlihat ketika memperoleh Peringkat III Nasional tentang pengelolaan daya tarik wisata (DTW) berwawasan lingkungan yang bertajuk Citra Pesona Wisata atau Citra Award pada tahun 2011. Penghargaan ini diberikan sebagai wujud apresiasi pemerintah terhadap pengelola daya tarik wisata agar senantiasa berkomitmen mengimplementasikan aspek lingkungan, ekonomi dan sosial budaya dalam pengelolaan daya tarik wisaata sehingga menghasilkan daya tarik wisata yang berkualitas, berkelanjutan dan berdaya saing internasional.

Namun dalam perkembangannya, Desa Budaya Kertalangu belum sepenuhnya menjadi daya tarik wisata unggulan. Hal ini bisa dilihat dari kondisi fisik yang ada di Desa Budaya Kertalangu. Minimnya perawatan dan pemeliharaan menyebabkan kerusakan terhadap fasilitas pendukung wisata di antaranya zona jogging track, bale bengong di kawasan jogging track, terbengkalainya beberapa bangunan dan tidak termanfaatkan serta kurangnya pemeliharaan lingkungan di sekitar kawasan desa budaya. Selain itu, ada beberapa program-program yang terhenti dan bahkan belum terlaksana sebagaimana konsep awal pendirian desa budaya ini. Hal ini tentu bertolak belakang atas prestasi yang diraih pada tahun 2011.

Artikel ini bertujuan untuk mengevaluasi pelaksanaan program pengembangan Desa Budaya Kertalangu sebagai daya tarik wisata alternatif di Kota Denpasar. Secara khusus, artikel ini disusun untuk menjawab beberapa permasalahan pelaksanaan program pengembangan Desa Budaya Kertalangu sebagai daya tarik wisata alternatif di Kota Denpasar dilihat dari aspek konteks, input, proses dan produk; kendala-kendala yang dihadapi dalam pelaksanaan program pengembangan Desa Budaya Kertalangu; dan dampak ekonomi, sosial budaya dan lingkungan pada masyarakat dari pelaksanaan program pengembangan Desa Budaya Kertalangu sebagai daya tarik wisata alternatif di Kota Denpasar.

\section{Teori dan Metode Penelitian}

Ada tiga teori yang dipakai dalam kajian ini yaitu teori evaluasi, teori pembangunan pariwisata berkelanjutan, dan teori pengembangan destinasi pariwisata. Arifin (2012) menyatakan bahwa evaluasi adalah suatu proses yang sistematis dan berkelanjutan untuk menentukan kualitas (nilai dan arti) daripada sesuatu berdasarkan pertimbangan dan kriteria tertentu untuk membuat suatu keputusan. Model evaluasi yang digunakan dalam penelitian ini yaitu model evaluasi CIPP yang dikembangkan oleh Daniel Stufflebeam. Stufflebeam (dalam Zhang, dkk, 2011:61) menyebutkan bahwa:

CIPP evaluation models is a comprehensive framework for conducting 
formative and summative evaluations of projects, personnel, products, organizations, and evaluation systems.

Model evaluasi CIPP merupakan kerangka kompreherensif untuk melakukan evaluasi formatif dan evaluasi sumatif terhadap proyek, personil, produk, organisasi maupun evaluasi sistem. CIPP merupakan singkatan dari context, input, process dan product. Context berisikan tentang tujuan suatu program; input menyediakan informasi tentang sumber daya yang tersedia, sarana/fasilitas yang dimiliki; process berisikan tentang pelaksanaan program-program sesuai dengan perencanaan dan product bertujuan untuk mengukur, dan menilai pencapaian program.

Teori pembangunan pariwisata berkelanjutan digunakan untuk menganalisis dampak ekonomi, sosial budaya dan lingkungan akibat pelaksanaan program pengembangan Desa Budaya Kertalangu. Kegiatan wisata dianggap berkelanjutan jika memenuhi beberapa kriteria yaitu mampu berlanjut secara lingkungan yang berarti tidak menimbulkan efek negatif bagi ekosistem setempat; secara sosial budaya dapat diterima oleh masyarakat lokal tanpa menimbulkan konflik; dan secara ekonomis menguntungkan dan layak artinya keuntungan tersebut mampu meningkatkan kesejahteraan masyarakat (Sunaryo, 2013).

Pengembangan suatu daerah menjadi daya tarik wisata agar menarik untuk dikunjungi wisatawan potensial harus memiliki tiga syarat (Mariati, 1985 dan Yoeti, 1987 dalam Sunaryo, 2013) yaitu daerah tersebut harus mempunyai apa yang disebut dengan something to see; something to do; something to buy. Something to see maksudnya daerah tersebut harus memiliki daya tarik khusus yang bisa dilihat wisatawan dan juga atraksi wisata yang dijadikan hiburan bila orang datang berkunjung. Something to do artinya harus disediakan fasilitas rekreasi atau wahana yang digunakan oleh wisatawan untuk beraktivitas seperti olahraga, berkesenian maupun hiburan. Something to buy artinya ditempat tersebut harus tersedia barangbarang cinderamata/kerajinan masyarakat yang bisa dibeli wisatawan sebagai oleh-oleh. Melalui teori pengembangan destinasi pariwisata, akan dilihat apakah Desa Budaya Kertalangu sudah memenuhi kriteria sebagai suatu daya tarik wisata atau belum.

Artikel ini menggunakan pendekatan kualitatif yang didukung dengan pendekatan kuantitatif. Menurut Sugiyono (2014), kedua metode tersebut dapat digunakan bersama-sama namun digunakan secara bergantian. Teknik pengumpulan data yang digunakan yaitu observasi lapangan, penyebaran kuesioner, wawancara, dokumentasi, dan focus group discussion. Data kuantitatif yang didapat dari penyebaran kuesioner, diukur dengan menggunakan skala Guttman. Perhitungan hasil kuesioner dilakukan dengan persentase menggunakan tipe jawaban "Ya" dan "Tidak". Total jawaban "Ya" dibagi jumlah responden dikalikan 100\%. Jumlah 
jawaban memberikan gambaran tanggapan responden terhadap kondisi masyarakat Desa Kesiman Kertalangu sebagai akibat pelaksanaan program pengembangan Desa Budaya Kertalangu.

Penelitian dilakukan di Desa Kesiman Kertalangu pada bulan April sampai dengan bulan Juni 2015. Populasi yang dimaksud dalam penelitian ini adalah kepala keluarga (KK) di Desa Kesiman Kertalangu yang berjumlah 2.767 KK (Profil Desa Kesiman Kertalangu tahun 2014). Jumlah total responden adalah 97 orang yang ditentukan dengan menggunakan rumus Slovin. Penentuan responden berdasarkan teknik disproportional stratified random sampling dan penentuan informan dilakukan dengan teknik purposive sampling.

Pelaksanaan program pengembangan Desa Budaya Kertalangu sebagai daya tarik wisata alternatif di Kota Denpasar ditinjau dari aspek konteks, input, proses dan produk dianalisis menggunakan analisis model evaluasi CIPP. Teknik analisis deskriptif kualitatif digunakan untuk membahas kendala-kendala yang dihadapi dalam pelaksanaan program pengembangan Desa Budaya Kertalangu melalui focus group discussion. Analisis ini juga digunakan untuk membahas dampak ekonomi, sosial budaya dan lingkungan pada masyarakat sebagai akibat pelaksanaan program pengembangan Desa Budaya Kertalangu yang diperoleh dari hasil persebaran kuesioner.

\section{Karakteristik Responden}

Jumlah sampel yang digunakan sebanyak 97 responden dan 5 informan. Responden berasal dari sebelas banjar yang ada di Desa Kesiman Kertalangu. Responden di Banjar Tohpati sebanyak 45 responden, di Banjar Kertalangu 12 responden, di Banjar Kertajiwa 10 responden, di Banjar Kesambi, Banjar Tangtu, Banjar Batursari, Banjar Biaung Asri, masing-masing 3 responden, di Banjar Biaung dan Banjar Tangguntiti masing-masing 4 responden, dan di Banjar Kertapura dan Banjar Kertagraha masing-masing 5 responden.

Penentuan jumlah responden dilakukan berdasarkan kedekatan lokasi penelitian dengan wilayah responden. Semakin dekat dengan lokasi penelitian, semakin banyak masyarakat yang dijadikan responden. Desa Budaya Kertalangu berada di Banjar Tohpati dan berbatasan dengan Banjar Kertajiwa dan Banjar Kertalangu. Oleh karena itu, responden terbanyak berada di Banjar Tohpati dan diikuti oleh Banjar Kertajiwa dan Banjar Kertalangu. Tabel 1 menunjukkan distribusi responden. 
Tabel 1 Distribusi Karakteristik Responden di Desa Kesiman Kertalangu

\begin{tabular}{|c|c|c|c|}
\hline $\begin{array}{c}\text { Karakteristik } \\
\text { Responden }\end{array}$ & $\begin{array}{c}\text { Distribusi } \\
\text { Responden }\end{array}$ & Jumlah Orang & Persentase \\
\hline \multirow[t]{3}{*}{ Jenis Kelamin } & Laki-laki & 54 & $55,67 \%$ \\
\hline & Perempuan & 43 & $44,33 \%$ \\
\hline & Jumlah & 97 & $100 \%$ \\
\hline \multirow[t]{5}{*}{ Kelompok Umur } & $15^{-20} \mathrm{Th}$ & 3 & $3,10 \%$ \\
\hline & 21-30 Th & 18 & $18,56 \%$ \\
\hline & $31-40 \mathrm{Th}$ & 19 & $19,58 \%$ \\
\hline & 41 Th ke atas & 57 & $58,76 \%$ \\
\hline & Jumlah & 97 & $100 \%$ \\
\hline \multirow[t]{6}{*}{ Jenjang Pendidikan } & $S D$ & 6 & $6,18 \%$ \\
\hline & $S M P$ & 7 & $7,22 \%$ \\
\hline & $S M A$ & 44 & $45,36 \%$ \\
\hline & DIPLOMA & 11 & $11,34 \%$ \\
\hline & SARJANA & 29 & $29,90 \%$ \\
\hline & Jumlah & 97 & $100 \%$ \\
\hline \multirow[t]{7}{*}{ Jenis Pekerjaan } & Buruh & 4 & $4,10 \%$ \\
\hline & Karyawan Swasta & 29 & $29,90 \%$ \\
\hline & Petani & 4 & $4,10 \%$ \\
\hline & PNS & 21 & $20,63 \%$ \\
\hline & Wiraswasta & 20 & $20,63 \%$ \\
\hline & Lain-lainnya & 19 & $19,60 \%$ \\
\hline & Jumlah & 97 & $100 \%$ \\
\hline
\end{tabular}

Sumber: Hasil Pengolahan Data, 2015

\section{Pengembangan Desa Budaya Kertalangu Ditinjau dari Aspek Konteks, Input, Proses dan Produk}

Pelaksanaan program pengembangan Desa Budaya Kertalangu dalam penelitian ini dianalisis dengan merujuk pada teori evaluasi CIPP (context, input, process, product). Uraian keempat aspek tersebut dijelaskan sebagai berikut.

\subsection{Aspek Konteks}

Pengembangan Desa Budaya Kertalangu dilihat dari tujuan programnya. Berdasarkan hasil wawancara dengan salah satu pengelola Desa Budaya Kertalangu disampaikan bahwa konsep awal berdirinya Desa Budaya Kertalangu adalah upaya pelestarian lingkungan dengan memasukkan konsep ekonomi melalui kegiatan wisata. Sesuai dengan master plan dokumen legalitas Desa Budaya Kertalangu, desa budaya ini bertujuan untuk melestarikan kehidupan Bali mula/tradisional melalui Desa Budaya Kertalangu untuk mencapai kesejahteraan masyarakat. 
Untuk mencapai tujuan tersebut, terdapat tujuh dimensi program yang disiapkan dan terinci ke dalam 45 item program. Ketujuh dimensi tersebut meliputi pertama, dimensi olahraga, kesehatan, kebugaran dan relaksasi. Dimensi ini terinci ke dalam lima kegiatan yaitu jogging di tengah sawah, komunitas senam yoga, gelanggang latihan berkuda, kolam renang latih/ turnamen dan spa relaksasi. Kedua, dimensi permainan, hiburan dan rekreasi. Dimensi ini terinci ke dalam tujuh kegiatan yaitu wisata kuliner, wisata berkuda, wisata dokar, wisata permainan tradisional, wisata air/ kolam renang/permainan air, wisata memancing, wisata outbound dan ketangkasan. Ketiga, dimensi pendidikan yang meliputi program pembuatan kompos, program seni kerajinan pot, program budi daya tanaman hias, program seni kerajinan gelas, program seni kerajinan gerabah/gentong, program seni kerajinan keramik, program seni kerajinan patung, dan program wisata pertanian tradisional.

Keempat, dimensi pelestarian seni, budaya dan religi. Dimensi ini meliputi pameran kesenian/produk seni, pentas seni budaya, pusat ritual Hindu, wujud rumah tradisional Bali, koleksi tanaman langka/tanaman gumi banten, dan program kursus/pelatihan kesenian tradisional. Kelima, dimensi sosial/kemasyarakatan yang meliputi program pelatihan SDM lokal, program pendampingan/pemberdayaan dan program pengelolaan aset masyarakat. Keenam, dimensi pariwisata/bisnis/ekonomi yang meliputi marketing/manajemen/EO, bisnis center \& meeting room, pusat informasi wisata, program transit wisata, pasar produksi rakyat/oleh-oleh Bali, pasar tradisional/ produk pertanian, pameran/display produk pot, gentong/gerabah, produk keramik, pusat pasar ritual Hindu, produk patung dan pusat pasar tanaman hias.

Ketujuh, dimensi pertanian, peternakan, perikanan dan kerajinan. Dimensi ini terinci ke dalam empat kegiatan. Di antaranya yaitu zonasi/relokasi, pendataan sistem (pertanian, peternakan, perikanan dan kerajinan), program pemasaran produk (pertanian, peternakan, perikanan dan kerajinan).

\subsection{Aspek Input}

Pada aspek input, dilihat dari ketersediaan personil, ketersediaan organisasi pendukung, dana/anggaran, sarana dan prasarana pendukung serta waktu yang dibutuhkan dalam pelaksanaan program pengembangan Desa Budaya Kertalangu. Berdasarkan hasil wawancara dengan salah satu pengelola, Desa Budaya Kertalangu berada di bawah naungan PT Desa Budaya Kertalangu (DBK) yang dipimpin oleh Bapak Agung Mahendra dan PT Bali Multi Wisata (BMW) yang dikelola oleh Bapak Made Sastrawan.

Dari ketersediaan personil, total pegawai yang bekerja di Desa Budaya Kertalangu berjumlah 61 orang yang terbagi ke dalam beberapa unit di antaranya di kolamg pancing 20 orang, trading 15 orang, gong perdamaian 
18 orang, Kampoeng oleh-oleh Kertalangu 8 orang. Dari kondisi tersebut, personil di Desa Budaya Kertalangu bisa dikatakan masih minim mengingat belum ada tenaga yang khusus diperuntukkan bagi aktivitas budaya seperti tenaga tari dan tabuh. Minimnya tenaga terlihat ketika pelaksanaan eventevent, ada fasilitas yang tidak beroperasi karena tenaga yang bertugas mengoperasikan dialihkan untuk mendukung pelaksanaan event.

Berdasarkan struktur organisasi Desa Budaya Kertalangu, ada 18 organisasi yang terlibat yang terdiri dari 17 instansi pemerintah di Kota Denpasar dan 1 lembaga koperasi. Instansi tersebut meliputi Dinas Pariwisata Kota Denpasar, Dinas Pendidikan, Dinas Koperasi, Usaha Kecil dan Menengah, Dinas Perindag, Dinas Kebersihan dan Pertamanan, Dinas Pendapatan, Dinas Pekerjaan Umum, Dinas Tata Kota, Dinas Pertanian Tanaman Pangan dan Hortikultura, Dinas Perhubungan, Dinas Trantib \& Satpol PP, Dinas Sosial, Badan Lingkungan Hidup, Kantor Peternakan, Bappeda Kota Denpasar, Badan Pemberdayaan masyarakat dan Pemerintah Desa, dan Camat Denpasar Timur. Organisasi lain yang juga termasuk pendukung bagi pengembangan Desa Budaya Kertalangu adalah Koperasi Saringumi.

Hasil wawancara dengan Bapak Dewa Kaler, dana pengembangan Desa Budaya Kertalangu hanya bersumber dari pihak pengelola (PT DBK dan PT BMW). Tidak ada kerja sama dengan pihak lain seperti Bank atau lembaga pinjaman lainnya. Berdasarkan hasil observasi, prasarana yang ada di Desa Budaya Kertalangu meliputi jalan, penerangan jalan, koperasi dan lahan persawahan. Sarana wisata meliputi 'Kampoeng Oleh-oleh Kertalangu', pusat kerajinan, restoran, stage, Gong Perdamaian, kolam pancing, jogging track, wisata berkuda, wahana permainan anak-anak seperti odong-odong, kereta kuda putar, rumah karet, trampolin, dan sarana ketangkasan seperti flying fox (Foto 1).

Pengembangan Desa Budaya Kertalangu membutuhkan waktu yang cukup lama. Dalam master plan tidak tercantum waktu yang dibutuhkan untuk pengembangan Desa Budaya Kertalangu. Berdasarkan hasil wawancara dengan Bapak Dewa Kaler, pada awal pendirian, telah dilakukan perhitungan untuk Break Event Point (BEP) \pm 12 tahun. Artinya uang yang ditanam demi pengembangan desa budaya ini akan kembali dalam jangka waktu 12 tahun ke depan sejak pembangunan dimulai, sekitar tahun 2019. Program-program yang telah dicanangkan akan dilakukan secara bertahap dan berkelanjutan.

\subsection{Aspek Proses}

Ada empat indikator yang dijadikan acuan untuk aspek proses yaitu pertama, bentuk promosi yang dilakukan. Berdasarkan hasil wawancara, promosi dilakukan oleh masing-masing pengelola. PT DBK melakukan 


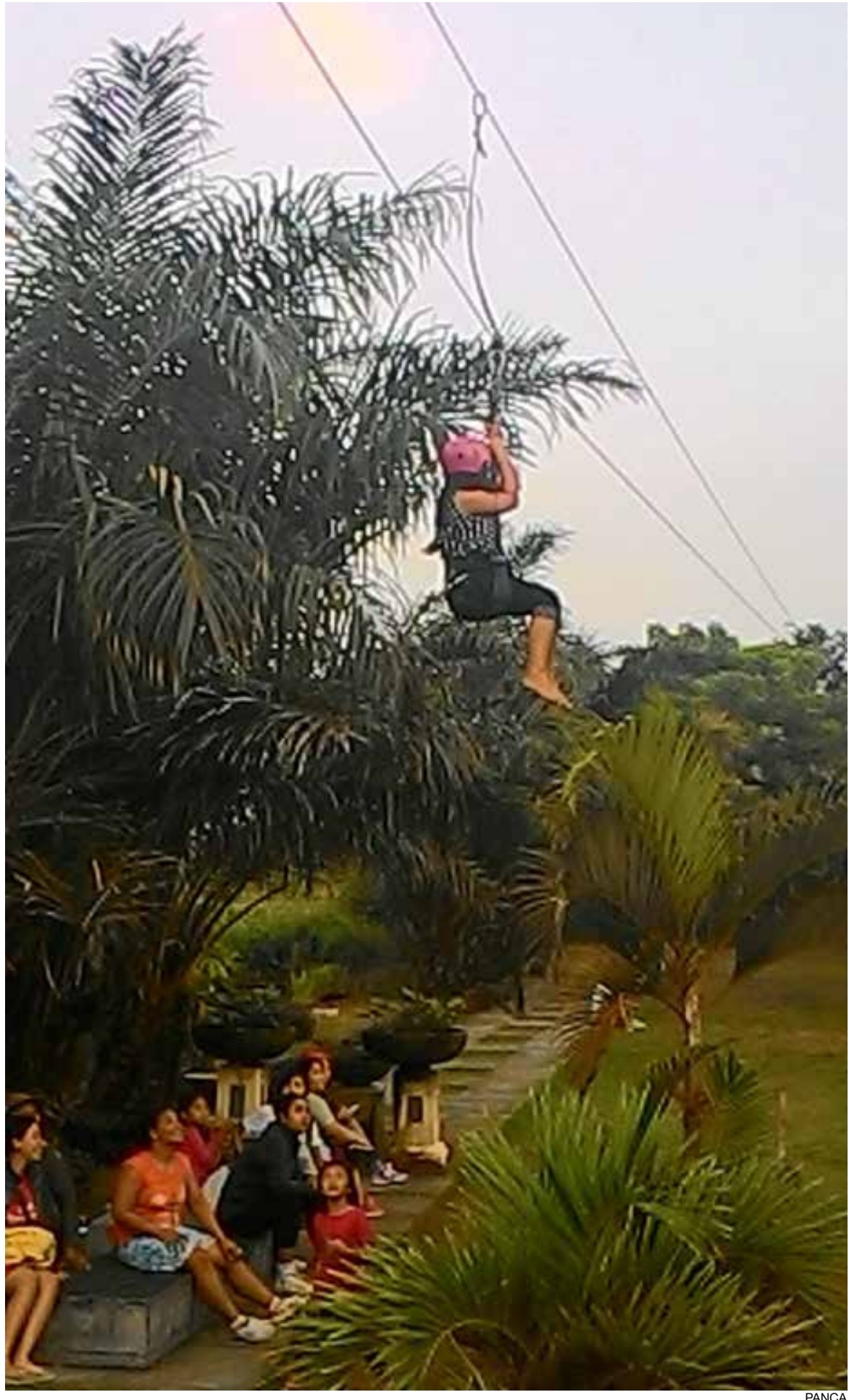

Foto 1. Aktivitas flying fox di Desa Budaya Kertalangu. 
promosi dengan pemasangan banner, melalui media elektronik seperti Bali TV dengan program Pesona Wisatanya. Promosi juga dilakukan oleh salah satu stasiun TV mancanegara yaitu TV 3 Malaysia melalui program "dari Kampoeng ke Kampoeng”.

PT Bali Multi Wisata juga tidak jauh beda dalam mempromosikan kegiatannya. Promosi yang dilakukan menggunakan media sosial, melalui sales call, termasuk pelaksanaan event-event yang diadakan di Desa Budaya Kertalangu secara otomatis ikut mempromosikan keberadaan desa budaya ini.

Promosi melalui website juga dilakukan oleh pihak pengelola. Melalui website www.desabudayakertalangu.com dan www.wpgpark. com, wisatawan dapat mengetahui segala informasi tentang Desa Budaya Kertalangu. Bentuk promosi lainnya yaitu dengan melakukan pendekatan terhadap seluruh travel yang ada di Bali. Melalui upaya ini, diharapkan para agen-agen perjalanan wisata (travel) bersedia mengajak wisatawan untuk berkunjung ke Desa Budaya Kertalangu.

Kedua, program-program yang terlaksana. Program-program yang telah dilaksanakan di Desa Budaya Kertalangu dan saat ini masih berjalan diuraikan pada Tabel 2.

Tabel 2. Capaian Program

\begin{tabular}{|c|c|c|c|}
\hline No & Dimensi Program & Program yang terlaksana & $\begin{array}{l}\text { Persen- } \\
\text { tase } \\
\text { Capaian }\end{array}$ \\
\hline 1. & $\begin{array}{l}\text { Dimensi olahraga, kesehatan, } \\
\text { kebugaran dan relaksasi ( } 5 \text { ke- } \\
\text { giatan) }\end{array}$ & $\begin{array}{l}\text { jogging track, komunitas senam } \\
\text { yoga, spa relaksasi }\end{array}$ & $60 \%$ \\
\hline 2 & $\begin{array}{l}\text { Dimensi permainan, hiburan, } \\
\text { rekreasi ( } 7 \text { kegiatan) }\end{array}$ & $\begin{array}{l}\text { wisata kuliner, wisata berkuda, } \\
\text { wisata memancing, wisata out- } \\
\text { bound dan ketangkasan, wisata } \\
\text { permainan anak-anak }\end{array}$ & $71,42 \%$ \\
\hline 3 & Dimensi pendidikan (8 kegiatan) & $\begin{array}{l}\text { program wisata pertanian tra- } \\
\text { disional, program seni kerajinan }\end{array}$ & $25 \%$ \\
\hline 4 & $\begin{array}{l}\text { Dimensi pelestarian seni, budaya } \\
\text { dan religi ( } 6 \text { kegiatan) }\end{array}$ & pentas seni budaya & $16,66 \%$ \\
\hline 5 & $\begin{array}{l}\text { Dimensi pariwisata /bisnis/ } \\
\text { ekonomi (12 kegiatan) }\end{array}$ & $\begin{array}{l}\text { marketing/manajemen/event } \\
\text { organizer (EO), bisnis center dan } \\
\text { meeting room, pasar produksi } \\
\text { rakyat/oleh-oleh Bali }\end{array}$ & $25 \%$ \\
\hline 6 & $\begin{array}{l}\text { Dimensi sosial kemasyarakatan ( } 3 \\
\text { kegiatan) }\end{array}$ & $\begin{array}{l}\text { program pengelolaan aset ma- } \\
\text { syarakat }\end{array}$ & $33,33 \%$ \\
\hline 7 & $\begin{array}{l}\text { Dimensi pertanian, peternakan, } \\
\text { perikanan dan kerajinan ( } 4 \\
\text { kegiatan) }\end{array}$ & $\begin{array}{l}\text { sosialisasi sistem dan pendamp- } \\
\text { ingan (pertanian) }\end{array}$ & $25 \%$ \\
\hline
\end{tabular}

Pada Tabel 2 dapat dilihat bahwa secara keseluruhan, dari 45 program kegiatan, yang masih terlaksana hanya 16 program kegiatan (35,55\%). 
Ketiga, pengawasan. Pengawasan dilakukan oleh Kepala Desa atas nama Desa Kesiman Kertalangu sesuai dengan perjanjian kerjasama Nomor: 24/ XII/o8/Pem, antara Desa Kesiman Kertalangu dengan I Dewa Gede Ngurah Rai tentang Pengembangan Pembangunan dan Pengelolaan Kawasan Desa Budaya Kertalangu. Hasil wawancara dengan Bapak Ida Bagus Bima Putra selaku Kepala Desa disampaikan bentuk pengawasan yang dilakukan yaitu memantau penataan, aktivitas maupun pemanfaatan tenaga kerja oleh pihak pengelola Desa Budaya Kertalangu.

Saat ini diketahui bahwa masih banyak program-program yang belum terwujud sempurna dan pihak desa rencananya akan mengumpulkan pihakpihak terkait untuk membahas keberlanjutan atau arah pengembangan Desa Budaya Kertalangu. Keempat, pemeliharaan. Kegiatan ini dilakukan secara rutin maupun berkala agar sarana yang ada dapat berfungsi dengan optimal. Berdasarkan hasil wawancara, kegiatan pemeliharaan dilakukan oleh masing-masing pengelola baik PT Desa Budaya Kertalangu maupun PT Bali Multi Wisata.

\subsection{Aspek Produk}

Ada tiga indikator yang dijadikan acuan dari aspek produk yaitu pertama, tingkat partisipasi masyarakat. Berdasarkan hasil wawancara dengan Bapak Wayan Warka selaku inisiator Desa Budaya Kertalangu, disampaikan bahwa partisipasi masyarakat sangat terbatas. Keterlibatan masyarakat hanya sebatas ikatan pekerjaan dan penyewaan lahan. Partisipasi yang terjadi hanya partisipasi pasif.

Kedua, tingkat kunjungan wisatawan ke Desa Budaya Kertalangu cukup banyak. Sesuai dengan data Dinas Pariwisata Kota Denpasar Tahun 2013, jumlah kunjungan wisatawan ke Desa Budaya Kertalangu adalah terbanyak ketiga setelah Pulau Serangan dan Monumen Perjuangan Rakyat Bali. Berdasarkan hasil wawancara dengan Bapak Dewa Kaler selaku marketing PT Desa Budaya Kertalangu, kunjungan wisatawan membludak ketika musim liburan maupun akhir pekan. Dalam sehari bisa mencapai 1000 orang. Angka kunjungan wisatawan ke objek wisata di Kota Denpasar dapat dilihat pada Tabel 3 .

Tabel 3 Angka Kunjungan Wisatawan ke Objek Wisata di Kota Denpasar Tahun 2013

\begin{tabular}{|c|c|c|c|c|}
\hline \multirow[b]{2}{*}{ No } & \multirow[b]{2}{*}{ Objek Wisata } & \multicolumn{2}{|c|}{ Jumlah Wisatawan } & \multirow[b]{2}{*}{ Total } \\
\hline & & $\begin{array}{c}\text { Mancaneg- } \\
\text { ara }\end{array}$ & Domestik & \\
\hline 1. & Museum Bali & 9.947 & 16.268 & 26.215 \\
\hline 2. & Museum Le Mayeur & 1.829 & 3.053 & 4.882 \\
\hline 3. & Art Center & 2.029 & 6.476 & 8.505 \\
\hline 4. & Pulau Serangan & 109.135 & 65.262 & 174.397 \\
\hline 5. & Prasasti Blanjong & 132 & 223 & 355 \\
\hline
\end{tabular}




\begin{tabular}{lrrr} 
6. Pasar Kumbasari & 13.267 & 0 & 13.267 \\
7. Pasar Badung & 18.395 & 0 & 18.395 \\
8. Museum Lukis Sidik Jari & 48 & 356 & 404 \\
9. Monumen Perjuangan Rakyat Bali & 18.958 & 111.297 & 130.255 \\
10. Mangrove & 0 & 3.877 & 3.877 \\
11. Pura Dalem Sakenan & 56 & 261 & 317 \\
12. Desa Budaya Kertalangu & $\mathbf{1 1 . 1 6 6}$ & $\mathbf{5 1 . 7 4 0}$ & $\mathbf{6 2 . 9 0 6}$ \\
13. Pura Mospahit Tonja & 0 & 0 & 0 \\
14. Pura Prasada Maospahit Grenceng & 0 & 0 & 0 \\
\hline
\end{tabular}

Sumber: Data Pariwisata Kota Denpasar Tahun 2013

Ketiga, persepsi wisatawan terhadap Desa Budaya Kertalangu. Berdasarkan wawancara terhadap wisatawan lokal yang berasal dari Kabupaten Gianyar disampaikan bahwa keberadaan Desa Budaya Kertalangu masih perlu dikembangkan. Wawancara kedua dilakukan terhadap rombongan wisatawan yang berasal dari Hongkong. Berdasarkan informasi dari guide nya, disampaikan bahwa kesan yang muncul dibenak wisatawan adalah Desa Budaya Kertalangu kurang bersih dan kurang terawat. Sampah berserakan dimana-mana dan toiletnya sangatlah jorok. Berdasarkan tanggapan kedua wisatawan tersebut, pengembangan Desa Budaya Kertalangu dalam hal pengelolaan kebersihan, pemanfaatan, dan pemeliharaan fasilitas agar lebih dioptimalkan.

\section{Kendala Pengembangan Desa Budaya Kertalangu}

Kendala-kendala yang dihadapi dalam rangka pengembangan Desa Budaya Kertalangu sebagai daya tarik wisata alternatif di Kota Denpasar dapat dilihat dari beberapa aspek. Berikut beberapa kendala-kendala yang dihadapi dalam pengembangan Desa Budaya Kertalangu.

Pertama, manajemen pengelolaan yang belum optimal. Berdasarkan hasil diskusi yang dilakukan terhadap salah satu insiator berdirinya Desa Budaya Kertalangu, Bapak Lunga Antara, menyampaikan bahwa pengelolaan Desa Budaya Kertalangu belum dikelola secara profesional. Dari aktivitas promosi, masing-masing pengelola, berjalan sendiri-sendiri dalam mempromosikan kegiatannya. Belum adanya pendataan tingkat kunjungan wisatawan. Dari kedua pengelola, belum menerapkan mekanisme pasti untuk mengetahui jumlah kunjungan wisatawan yang datang ke Desa Budaya Kertalangu.

Saat ini, untuk masuk ke Desa Budaya Kertalangu hanya dikenakan ongkos parkir. Jika mengacu pada karcis parkir yang terpakai, maka jumlah wisatawan yang datang tidak dapat diketahui dengan akurat. Bisa saja dalam satu kendaraan, dikenakan 1 karcis parkir, namun di dalamnya terdapat 2 orang atau lebih. Hal ini menyebabkan pendataan wisatawan belum dapat dilakukan dengan jelas. Pengelolaan kebersihan saat ini hanya terbatas 


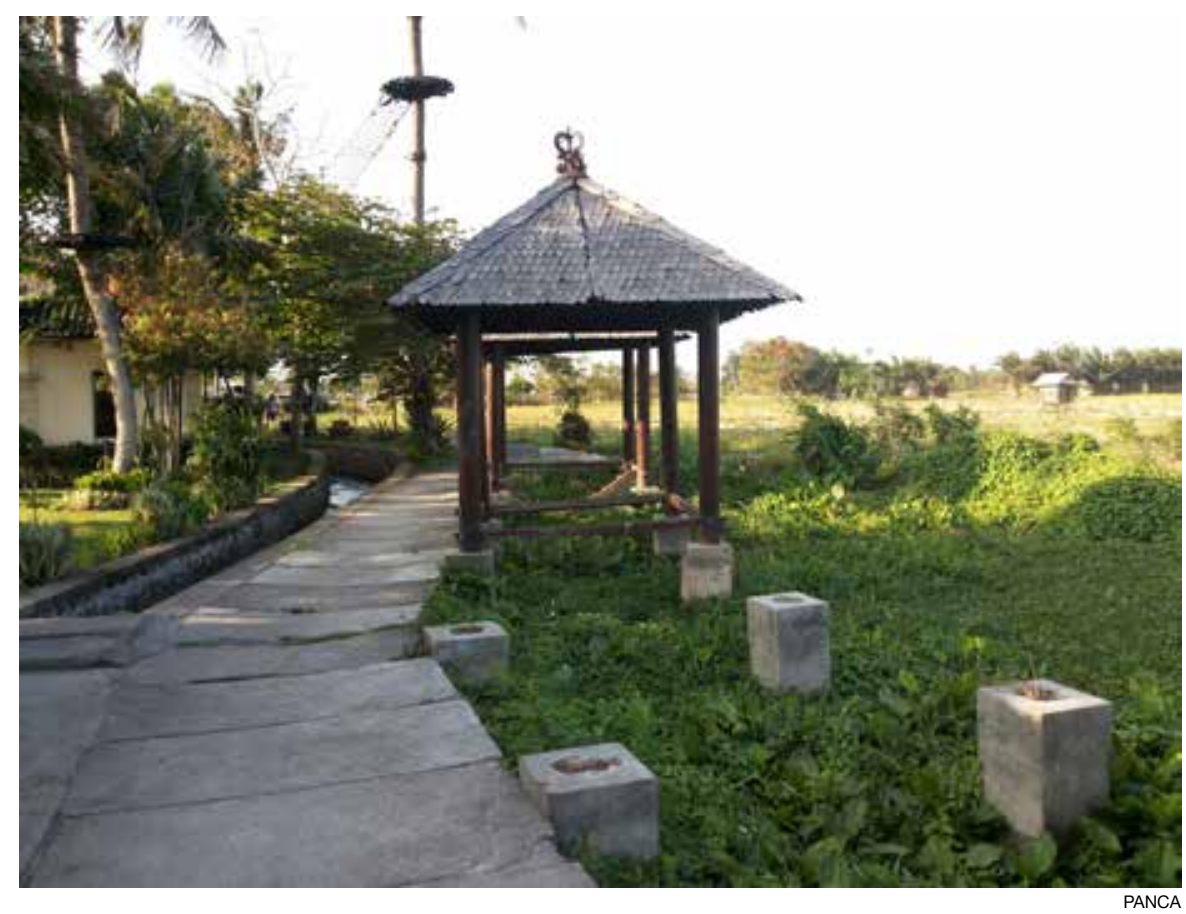

Foto 2. Gazebo yang sebelumnya ada di jalur Jogging Track.

pada unit-unit tertentu saja. Pengelolaan kebersihan tidak dilakukan secara menyeluruh, artinya seluruh kebersihan kawasan yang ada di Desa Budaya Kertalangu menjadi tanggung jawab pengelola baik PT Desa Budaya Kertalangu maupun PT Bali Multi Wisata.

Kedua, terbatasnya anggaran yang dialokasikan untuk pengembangan potensi wisata. Berdasarkan hasil diskusi dengan salah satu pengelola, Bapak Dewa Kaler, disampaikan bahwa kendala utama yang dihadapi dalam pelaksanaan pengembangan Desa Budaya Kertalangu adalah terbatasnya dana/anggaran. Selama ini, tingkat pendapatan yang diperoleh lebih kecil dibandingkan dengan tingkat pengeluaran. Pengeluaran yang terbesar yaitu biaya pemeliharaan terhadap fasilitas yang ada di desa budaya. Jika kita melihat kondisi di lapangan, ada beberapa fasilitas yang tidak terawat dan bahkan tidak dapat dipertahankan (Foto 2).

Dengan keterbatasan dana tersebut, ada beberapa program yang terhenti dan bahkan belum terlaksana sesuai konsep awal pendirian Desa Budaya Kertalangu. Salah satunya yaitu program layanan wisata budaya seperti tari kecak, tari barong, tidak dapat dilaksanakan secara reguler karena kalah saing dengan tempat lain yang menyediakan layanan yang sama seperti barong dance yang ada di Jalan Waribang, Kesiman ataupun yang ada di Batubulan.

Ketiga, koordinasi antar pihak pengelola dan pihak pengelola dengan 
pihak Desa Kesiman Kertalangu terkait dengan pengelolaan kawasan belum terjalin dengan baik. Hal ini terlihat di beberapa titik kawasan Desa Budaya Kertalangu, di antaranya yaitu:

a. Ada beberapa titik pada jalur jogging track yang terbengkalai dan tidak terawat sehingga mempengaruhi pandangan dan mengganggu jalur pengunjung yang sedang melakukan jogging. Hal ini tentu berpengaruh terhadap kenyamanan pengunjung yang dominan melakukan aktivitas olahraga di area ini. Berdasarkan hasil wawancara dengan salah satu pengelola disampaikan bahwa pengelolaan termasuk pemeliharaan terhadap jalur jogging track menjadi kewajiban desa namun hal ini dibantah oleh salah satu inisiator pendiri Desa Budaya Kertalangu, Bapak Warka. Beliau menyebutkan bahwa pengelolaan maupun pemeliharaan jalur jogging track menjadi kewajiban pengelola bersama pihak desa. Hal ini terlihat bahwa koordinasi antara pihak pengelola dengan desa masih belum optimal sehingga masih terdapat perbedaan persepsi terkait dengan pemeliharaan dan pengelolaan kawasan ini.

b. Ada beberapa fasilitas pendukung yang tidak mendapat pengelolaan dan pemeliharaan dengan baik. Fasilitas toilet umum yang berada di area terdepan kawasan Desa Budaya Kertalangu merupakan salah satu di antaranya. Toilet ini merupakan fasilitas yang paling sering digunakan oleh wisatawan ketika berkunjung ke suatu tempat. Kebersihan maupun kenyamanan fasilitas umum menjadi salah satu penilaian dari pengunjung. Ketika fasilitas yang diterima kurang baik/ nyaman, maka wisatawan akan berpikir kembali untuk melakukan kunjungan (Foto 3).

\section{Dampak Pengembangan Desa Budaya Kertalangu}

Pengembangan pariwisata akan berdampak bagi daerah tersebut baik terhadap kondisi alam, sosial budaya maupun kondisi ekonomi masyarakatnya. Hal yang sama juga terjadi terhadap pengembangan Desa Budaya Kertalangu. Disadari atau tidak, pengembangan Desa Budaya Kertalangu akan memberikan dampak secara langsung bagi masyarakat sekitarnya.

Secara sederhana, dampak dapat diartikan sebagai pengaruh atau akibat. Pada artikel ini, dampak yang ditimbulkan dilihat dari tiga aspek yaitu aspek ekonomi, aspek sosial budaya dan aspek lingkungan. Berdasarkan hasil sebaran kuesioner terhadap 97 responden yang berada di sebelas banjar di Desa Kesiman Kertalangu yang dianalisis dengan skala Guttman, diketahui tanggapan responden terhadap pelaksanaan program pengembangan Desa Budaya Kertalangu sebagai daya tarik wisata alternatif di Kota Denpasar. Uraian dampak-dampak tersebut dapat dijelaskan sebagai berikut. 


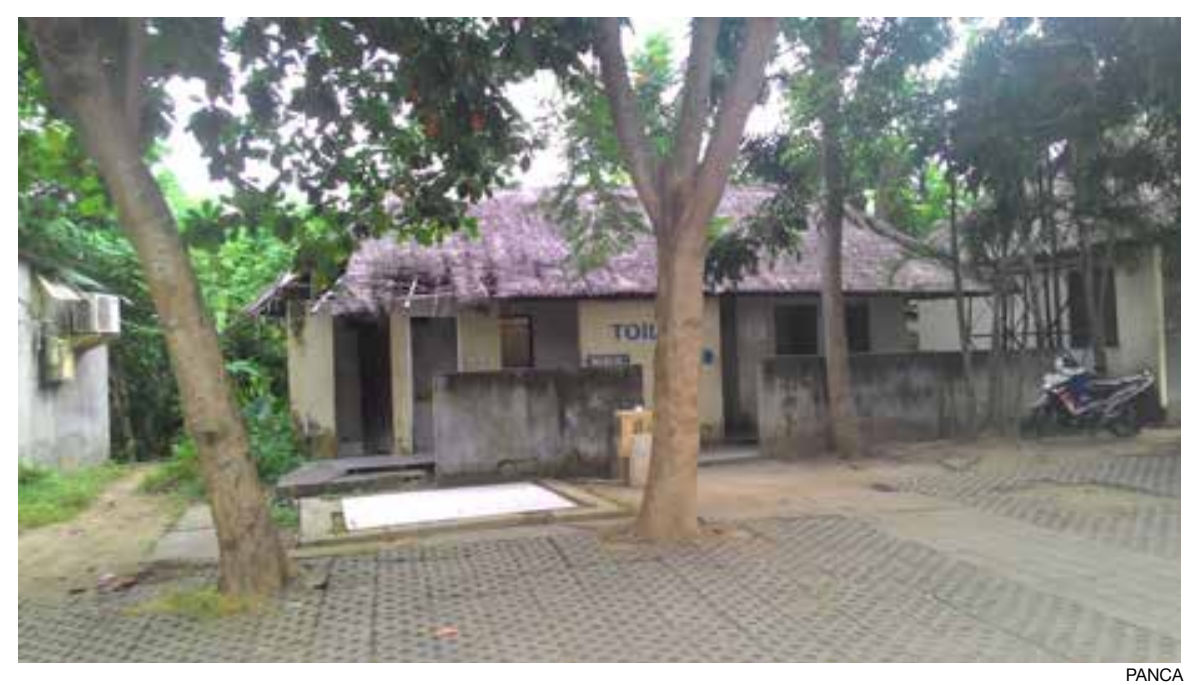

Foto 3. Fasilitas Toilet Umum yang tidak terkelola dengan baik.

\subsection{Dampak Ekonomi}

Cohen (dalam Pitana dan Gayatri, 2005) menyebutkan bahwa dampak pariwisata terhadap kondisi ekonomi masyarakat lokal dapat dikategorikan menjadi delapan kelompok besar yaitu dampak terhadap penerimaan devisa, pendapatan masyarakat, kesempatan kerja, harga-harga, distribusi manfaat/keuntungan, kepemilikan dan kontrol, pembangunan dan pendapatan pemerintah. Dalam penelitian ini, ada empat indikator yang dijadikan acuan terhadap dampak yang ditimbulkan. Keempat indikator tersebut memperoleh tanggapan dari responden berdasarkan hasil sebaran kuesioner sesuai Tabel 4.

Tabel 4 Dampak Pelaksanaan Program Pengembangan Desa Budaya Kertalangu Dilihat dari Aspek Ekonomi

\begin{tabular}{clccc}
\hline No. & \multicolumn{1}{c}{ Indikator } & $\begin{array}{c}\text { Jawaban } \\
\text { Ya (Jml) }\end{array}$ & $\begin{array}{c}\text { Jawaban } \\
\text { Tidak (Jml) }\end{array}$ & $\begin{array}{c}\text { Persentase } \\
\text { Jawaban Ya }\end{array}$ \\
\hline 1. & Peningkatan pendapatan masyarakat & 61 & 36 & $62,88 \%$ \\
2. & Mengurangi tingkat pengangguran & 79 & 18 & $81,44 \%$ \\
3. & Terbukanya lapangan kerja & 65 & 32 & $67,01 \%$ \\
4. Pemasaran produksi petani/pengrajin & 18 & 79 & $18,55 \%$ \\
\hline
\end{tabular}

Sumber: Hasil pengolahan data, 2015

Pada Tabel 4, dilihat dari indikator peningkatan pendapatan masyarakat, berdasarkan hasil persebaran kuesioner dapat diketahui bahwa sebagian besar responden $(62,88 \%)$ menyatakan bahwa dampak pelaksanaan program pengembangan Desa Budaya Kertalangu sebagai daya tarik wisata alternatif di Kota Denpasar berpengaruh terhadap peningkatan 
pendapatan masyarakat. Menurut responden, pendapatan yang diperoleh dari keberadaan desa budaya ini terutama bagi yang lahannya disewa untuk pengembangan Desa Budaya Kertalangu. Ada 17 orang di Desa Kesiman Kertalangu yang terikat perjanjian sewa terkait dengan pemanfaatan lahan di Desa Budaya Kertalangu. Lahan-lahan tersebut disewa dalam jangka waktu yang berbeda-beda berkisar 5 sampai dengan 30 tahun. Perjanjian sewa tersebut dimulai pada rentang tahun 2005 sampai dengan tahun 2008 dengan total lahan seluas $43075 \mathrm{~m}^{2}$.

Dari indikator tingkat pengangguran, sebanyak $81,44 \%$ responden menyatakan bahwa dampak pelaksanaan program pengembangan desa budaya ini berpengaruh terhadap berkurangnya tingkat pengangguran di Desa Kesiman Kertalangu. Di beberapa banjar, terutama Banjar Tohpati, ada masyarakat yang akhirnya memperoleh pekerjaan walaupun jumlahnya tidak banyak seperti Bapak Cakra dan Bapak Sudra yang bekerja sebagai tukang parkir dan Bapak Tantra dari Banjar Kertajiwa. Hal yang sama jika dilihat dari indikator terbukanya lapangan kerja dan usaha baru, sebanyak $67,01 \%$ responden menyatakan bahwa pelaksanaan program pengembangan Desa Budaya Kertalangu sebagai daya tarik wisata alternatif memberikan kesempatan adanya lapangan kerja/usaha baru bagi masyarakat Desa Kesiman Kertalangu. Usaha ini muncul ketika ada diselenggarakannya event-event di desa budaya. Ada sebagian masyarakat yang memanfaatkan momen tersebut untuk membuka usaha dagang.

Sebaliknya, dari indikator pemasaran produksi petani/pengrajin lokal, hanya $18,55 \%$ responden yang menyatakan bahwa pelaksanaan pengembangan Desa Budaya Kertalangu berperan dalam pemasaran produksi pertanian. Selama ini, para petani lebih dominan memasarkan sendiri hasil pertanian mereka sedangkan untuk kerajinan lokal, tidak banyak masyarakat yang bergelut di bidang itu. Berdasarkan keempat indikator yang dijadikan acuan, sebagian besar masyarakat menyatakan bahwa pelaksanaan program pengembangan Desa Budaya Kertalangu sebagai daya tarik wisata alternatif dilihat dari aspek ekonomi memberikan dampak terhadap kehidupan masyarakat Desa Kesiman Kertalangu, kecuali dalam hal pemasaran produksi petani/pengrajin lokal.

\subsection{Dampak Sosial Budaya}

Dampak sosial adalah konsekuensi sosial yang timbul akibat adanya suatu kegiatan pembangunan maupun penerapan suatu kebijaksanaan dan program dan merupakan perubahan yang terjadi pada manusia dan masyarakat yang diakibatkan oleh aktivitas pembangunan (Hadi, 1995 dalam Nurjanah, 2012). Dalam penelitian ini, ada enam indikator yang dijadikan acuan dalam menilai dampak sosial yang ditimbulkan. Hasil persebaran kuesioner terhadap keenam indikator tersebut dapat dilihat pada Tabel 5 . 
Tabel 5 Dampak Pelaksanaan Pengembangan Desa Budaya Kertalangu Dilihat dari Aspek Sosial Budaya

\begin{tabular}{clccc}
\hline No. & \multicolumn{1}{c}{ Indikator } & $\begin{array}{c}\text { Jawaban } \\
\text { Ya (Jml) }\end{array}$ & $\begin{array}{c}\text { Jawaban } \\
\text { Tidak (Jml) }\end{array}$ & $\begin{array}{c}\text { Persentase } \\
\text { Jawaban Ya }\end{array}$ \\
\hline 1. & Tingkat kerukunan masyarakat & 8 & 89 & $8,24 \%$ \\
& $\begin{array}{l}\text { Peningkatan kegiatan pelestarian } \\
\text { 2. }\end{array}$ & 77 & 20 & $79,38 \%$ \\
k. & Pesenian tradisional & 4 & 93 & $4,12 \%$ \\
& Perubahan tingkat pendidikan & 48 & 49 & $49,48 \%$ \\
4. & pencaharian tingkat mata & 3 & 94 & $3,09 \%$ \\
5. & Perubahan penguasaan bahasa & 78 & 19 & $80,41 \%$ \\
6. & Pemanfaatan SDM lokal & & & \\
\hline
\end{tabular}

Sumber: Hasil pengolahan data, 2015

Berdasarkan hasil persebaran kuesioner, menyatakan bahwa pelaksanaan program pengembangan Desa Budaya Kertalangu sebagai daya tarik wisata alternatif di Kota Denpasar tidak berpengaruh terhadap tingkat kerukunan masyarakat Desa Kesiman Kertalangu. Kerukunan masyarakat tercipta karena masih terjaganya rasa kebersamaan, kekeluargaan, untuk setiap kegiatan maupun rutinitas lain yang membuat ikatan emosional mereka semakin erat.

Kegiatan pelestarian kesenian tradisional, menurut sebagian besar responden $(79,38 \%)$ terjadi peningkatan. Keberadaan desa budaya ini merangsang aktifnya sekaha-sekaha yang ada di masing-masing banjar. Tidak hanya sekaha anak-anak, namun dari sekaha remaja sampai tingkat ibu-ibu pun aktif untuk melakukan kegiatan seni terutama menabuh. Hal ini karena pada event-event tertentu, sekaha-sekaha ini disediakan ruang untuk pentas di Desa Budaya Kertalangu seperti halnya ada kegiatan semarak budaya yang dilakukan pada bulan Maret 2015. Kegiatan seni dan budaya dari masing-masing banjar ditampilkan di Desa Budaya Kertalangu tepatnya di Gong Perdamaian.

Dilihat dari indikator perubahan tingkat pendidikan, dari 97 responden, sebanyak 4,12\% responden menyatakan bahwa pelaksanaan program pengembangan Desa Budaya Kertalangu sebagai daya tarik wisata alternatif di Kota Denpasar mempengaruhi keinginan masyarakat Desa Kesiman Kertalangu untuk meningkatkan pendidikan anak-anaknya di bidang pariwisata. Dilihat dari indikator perubahan mata pencaharian, dari 97 responden, sebanyak 49,48\% responden menyatakan pengembangan desa budaya kertalangu menyebabkan masyarakat Desa Kesiman Kertalangu beralih menjadi pekerja di bidang pariwisata. Namun kondisi yang ada di lapangan, keberadaan desa budaya ini tidak terlalu mempengaruhi mata pencaharian penduduk. Mengingat sebagian besar masyarakat di Desa Kesiman Kertalangu telah memiliki mata pencaharian yang tetap seperti karyawan, PNS, buruh, wiraswasta dan menjadikan pekerjaan di Desa Budaya Kertalangu hanya sebagai pekerjaan sampingan. 
Dilihat dari indikator perubahan penguasaan bahasa, berdasarkan hasil penelitian, sebanyak 3,09\% responden menyatakan bahwa pelaksanaan program pengembangan Desa Budaya Kertalangu sebagai daya tarik wisata alternatif di Kota Denpasar menyebabkan masyarakat Desa Kesiman Kertalangu berkeinginan untuk mempelajari bahasa asing. Murphy (dalam Pitana dan Gayatri, 2005) menyatakan bahwa kalangan muda merupakan kelompok yang paling rentan terhadap demonstration effect, salah satunya yaitu proses pembelajaran bahasa asing. Demonstration effect dalam penelitian ini yaitu efek meniru yang dilakukan oleh masyarakat dalam penggunaan bahasa sehingga mampu bersosialisasi dengan wisatawan. Menurut masyarakat, adanya keinginan untuk mempelajari bahasa asing hanya bagi mereka yang memang terjun langsung di Desa Budaya Kertalangu. Itu pun karena kunjungan wisatawan asing sangatlah minim dan kalaupun ada, para wisatawan telah didampingi oleh guide dari luar.

Dilihat dari indikator pemanfaatan sumber daya manusia lokal, dari 97 responden, sebanyak $80,41 \%$ responden menyatakan bahwa pelaksanaan program pengembangan Desa Budaya Kertalangu sebagai daya tarik wisata alternatif di Kota Denpasar telah memanfaatkan tenaga lokal. Menurut responden bahwa keberadaan Desa Budaya Kertalangu telah memberdayakan masyarakat setempat sebagai tenaga kerja seperti sebagai tenaga satpam maupun tukang parkir. Walaupun tidak terlalu banyak, namun masyarakat lokal lebih diutamakan. Hal ini dikarenakan untuk bekerja di Desa Budaya Kertalangu harus memenuhi standar-standar yang ditentukan.

\subsection{Dampak Lingkungan}

Ditinjau dari aspek lingkungan (fisik), ada dua indikator yang dijadikan acuan dalam menilai dampak yang ditimbulkan. Hasil kuesioner terhadap kedua indikator tersebut dapat dilihat pada Tabel 6.

Tabel 6 Dampak Pengembangan Desa Budaya Kertalangu Dilihat dari Aspek Lingkungan Fisik

\begin{tabular}{clccc}
\hline No. & \multicolumn{1}{c}{ Indikator } & $\begin{array}{c}\text { Jawaban } \\
\text { Ya (Jml) }\end{array}$ & $\begin{array}{c}\text { Jawaban } \\
\text { Tidak (Jml) }\end{array}$ & $\begin{array}{c}\text { Persentase } \\
\text { Jawaban Ya }\end{array}$ \\
\hline 1. & Tingkat pelestarian lingkungan & 92 & 5 & $94,84 \%$ \\
2. & Tingkat pencemaran & 2 & 95 & $2,06 \%$ \\
\hline
\end{tabular}

Sumber: Hasil pengolahan data, 2015

Tabel 6 menunjukkan bahwa sebanyak 94,84\% responden menyatakan pelaksanaan program pengembangan Desa Budaya Kertalangu sebagai daya tarik wisata alternatif di Kota Denpasar berpengaruh terhadap tingkat pelestarian lingkungan di Desa Kesiman Kertalangu. Upaya pelestarian dapat dilihat dari kegiatan desa untuk melakukan penghijauan di Desa Kesiman Kertalangu dengan dukungan dana sebesar 5\% berdasarkan hasil 


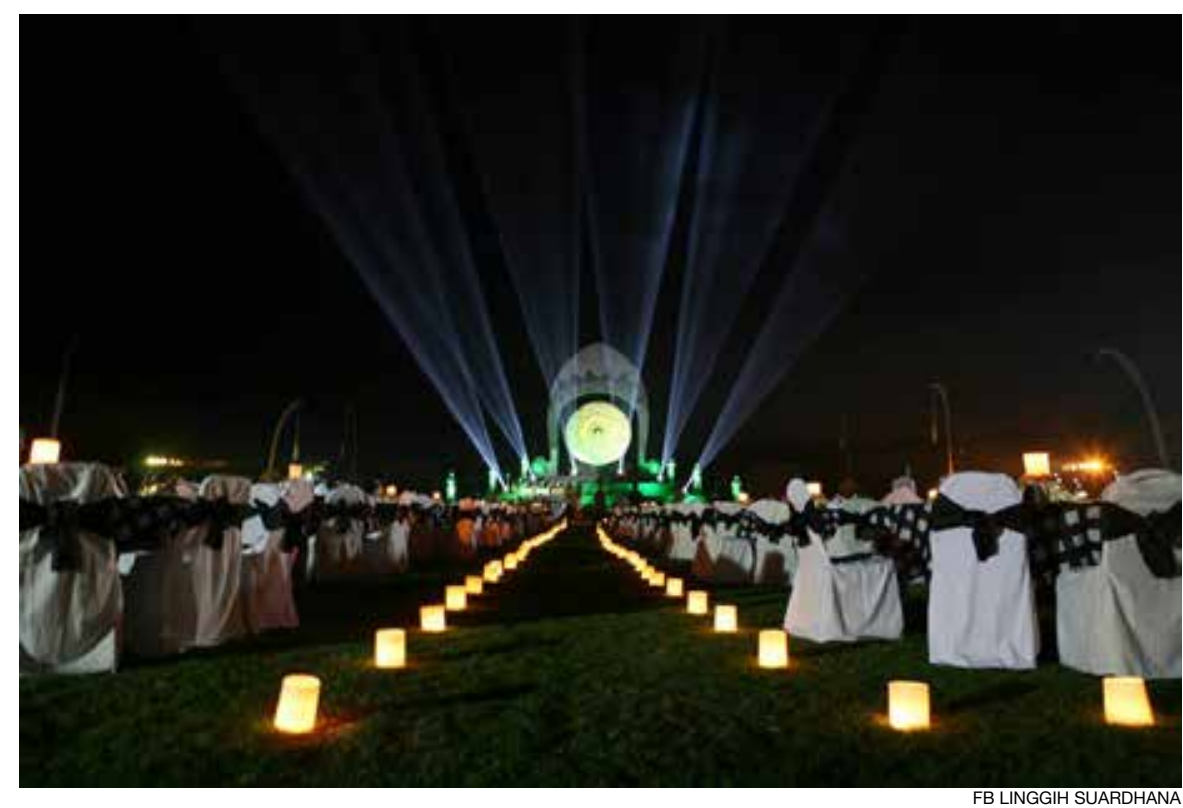

Gong Perdamaian di Kertalangu.

bagi usaha dari pengelola Desa Budaya Kertalangu dan mempertahankan lahan pertanian dari alih fungsi lahan yang terjadi di Kota Denpasar.

Dilihat dari indikator tingkat pencemaran terhadap lingkungannya, dari 97 responden, sebanyak 2,06\% responden menyatakan bahwa pelaksanaan program pengembangan Desa Budaya Kertalangu sebagai daya tarik wisata alternatif di Kota Denpasar mempengaruhi pencemaran lingkungan di Desa Kesiman Kertalangu. Hal ini berarti pengembangan Desa Budaya Kertalangu tidak memberikan efek negatif terhadap kondisi lingkungan di Desa Kesiman Kertalangu.

Berdasarkan hasil penelitian terhadap sebaran kuesioner yang dilihat dari aspek ekonomi, sosial budaya dan lingkungan menunjukkan bahwa sebagian besar responden menyatakan pelaksanaan program pengembangan Desa Budaya Kertalangu sebagai daya tarik wisata alternatif di Kota Denpasar memberikan dampak terhadap kondisi masyarakat di Desa Kesiman Kertalangu. Dari 12 indikator yang disebarkan, 8 indikator memberikan dampak positif bagi kehidupan masyarakat Desa Kesiman Kertalangu namun 4 indikator lainnya masih belum.

Dari aspek ekonomi, pengembangan Desa Budaya Kertalangu secara ekonomis mampu memberikan keuntungan dalam rangka meningkatkan kesejahteraan masyarakat (economically viable). Masyarakat menyatakan pengembangan Desa Budaya Kertalangu memberikan dampak terhadap adanya perubahan peningkatan pendapatan/penghasilan masyarakat lokal, mengurangi pengangguran dan terbukanya lapangan kerja dan usaha 
baru. Namun di sisi lain, pengembangan Desa Budaya Kertalangu perlu dioptimalkan lagi sehingga mampu berperan dalam pemasaran produksi petani lokal.

Dari aspek sosial budaya, pengembangan Desa Budaya Kertalangu belum sepenuhnya mampu memberikan kontribusi positif terhadap masyarakat Desa Kesiman Kertalangu (socially \& culturally acceptable). Masyarakat menyatakan pengembangan Desa Budaya Kertalangu mampu berkontribusi terhadap peningkatan kegiatan pelestarian kesenian masyarakat, telah mengutamakan sumber daya manusia lokal sebagai tenaga kerja dan tidak menyebabkan konflik internal masyarakat Desa Kesiman Kertalangu. Namun pengembangan desa budaya ini tidak memberikan pengaruh terhadap mata pencaharian masyarakat menjadi pekerja di bidang pariwisata, keinginan masyarakat untuk menyekolahkan anaknya di bidang pariwisata termasuk memberikan pendidikan/kursus bahasa asing.

Dari aspek lingkungan, pengembangan Desa Budaya Kertalangu tidak menimbulkan efek negatif bagi ekosistem setempat (environmentally sustainable). Masyarakat menyatakan bahwa pengembangan desa budaya berkontribusi terhadap upaya pelestarian lingkungan dan tidak melakukan pencemaran terhadap lingkungan di Desa Kesiman Kertalangu.

Pariwisata berkelanjutan adalah sebuah proses dan sistem pembangunan pariwisata yang dapat menjamin keberlangsungan sumber daya alam, kehidupan sosial budaya dan ekonomi hingga generasi yang akan datang. Menurut Sunaryo (2013), bahwa kegiatan wisata dianggap berkelanjutan jika pembangunan pariwisata tidak menimbulkan efek negatif bagi ekosistem/ lingkungan setempat (environmentally sustainable), secara sosial budaya kegiatan ini dapat diterima yaitu mengacu pada kemampuan masyarakat lokal untuk menyerap aktivitas pariwisata tanpa menimbulkan konflik sosial (socially \& culturally acceptable) dan secara ekonomi, kegiatan wisata dapat meningkatkan kesejahteraan masyarakat lokal (economically viable).

Sebagian besar kriteria ini telah dipenuhi sesuai dengan hasil sebaran kuesioner terhadap indikator-indikator yang telah ditentukan. Jika dikaitkan dengan teori pembangunan pariwisata berkelanjutan, maka pengembangan Desa Budaya Kertalangu sebagai daya tarik wisata alternatif sudah menerapkan prinsip-prinsip pariwisata berkelanjutan namun pada aspek ekonomi dan aspek sosial budaya perlu dioptimalkan karena masih ada indikator-indikator yang belum terpenuhi.

\section{Simpulan}

Berdasarkan hasil pembahasan yang telah diuraikan sebelumnya, maka dapat dikemukakan simpulan sebagai berikut:

Pertama, pelaksanaan program pengembangan Desa Budaya Kertalangu sebagai daya tarik wisata alternatif di Kota Denpasar ditinjau dari aspek 
konteks menunjukkan bahwa pengembangan Desa Budaya Kertalangu bertujuan untuk melestarikan lingkungan dengan memasukkan konsep ekonomi melalui kegiatan wisata. Ditinjau dari aspek input tampak bahwa ketersediaan personil masih minim terutama ketersediaan tenaga tari dan tabuh. Ditinjau dari aspek proses, tampak bahwa masih banyak programprogram yang belum terlaksana, salah satunya yaitu wisata air dan bahkan terhenti seperti program spa relaksasi. Hanya 16 program yang terlaksana dari 45 item program.

Ditinjau dari aspek produk diketahui bahwa tingkat partisipasi masyarakat masih rendah dan pengelolaan potensi wisata masih perlu dikembangkan, meskipun tingkat kunjungan wisatawan dapat dikatakan cukup banyak. Secara keseluruhan, Desa Budaya Kertalangu sudah layak disebut sebagai daya tarik wisata karena kawasan tersebut mempunyai apa yang disebut something to see, something to do dan something to buy. Hanya saja masih ada fasilitas yang keberadaannya kurang mendapat perhatian, salah satunya toilet. Berdasarkan kondisi tersebut, dapat disimpulkan bahwa pengelolaan Desa Budaya Kertalangu sebagai daya tarik wisata alternatif di Kota Denpasar belum berjalan dengan optimal.

Kedua, kendala-kendala yang dihadapi dalam pelaksanaan program pengembangan Desa Budaya Kertalangu sebagai daya tarik wisata alternatif di Kota Denpasar yaitu manajemen pengelolaan yang belum optimal terutama dalam hal promosi dan pengelolaan kebersihan kawasan; terbatasnya anggaran yang dialokasikan untuk pengembangan potensi wisata; dan koordinasi antar pihak pengelola dan antara pihak pengelola dengan pihak Desa Kesiman Kertalangu belum berjalan dengan baik.

Ketiga, dampak pelaksanaan program pengembangan Desa Budaya Kertalangu sebagai daya tarik wisata alternatif di Kota Denpasar ditinjau dari aspek ekonomi, sosial budaya dan lingkungan. Dari 12 indikator, 8 indikator menyatakan berpengaruh positif terhadap kehidupan masyarakat Desa Kesiman Kertalangu dan 4 indikator lainnya masih belum optimal. Atas kondisi ini, pengembangan Desa Budaya Kertalangu sudah menerapkan prinsip-prinsip pembangunan pariwisata berkelanjutan namun perlu dioptimalkan lagi.

Berdasarkan hasil analisis dan simpulan yang telah disampaikan, maka ada beberapa saran yang dapat disampaikan yaitu:

Pertama, terbatasnya anggaran yang dialokasikan untuk pengembangan potensi wisata mengharuskan pihak pengelola untuk melakukan upaya agar mampu menarik minat investor untuk menanamkan modalnya di Desa Budaya Kertalangu.

Kedua, perlu dilakukan koordinasi dan komunikasi yang intensif antar pihak pengelola maupun antara pihak pengelola dengan pihak Desa Kesiman Kertalangu sehingga terdapat persepsi yang sama terhadap pengembangan 
Desa Budaya Kertalangu untuk mencapai tujuan yang diharapkan.

Ketiga, partisipasi masyarakat dalam pengelolaan Desa Budaya Kertalangu agar lebih ditingkatkan dan peran serta Pemerintah selaku pengambil kebijakan agar memberikan insentif dan kemudahan dari sisi regulasi.

Keempat, penelitian ini merupakan penelitian evaluasi pada tahap pelaksanaan pengembangan Desa Budaya Kertalangu sehingga masih banyak kekurangan dan memerlukan penyempurnaan. Kepada peneliti lainnya diharapkan dapat mengembangkan penelitian ini pada tahap evaluasi pasca pelaksanaan sehingga dapat diketahui apakah tujuan pengembangan Desa Budaya Kertalangu tercapai atau tidak.

\section{Ucapan Terimakasih}

Artikel ini tersusun dengan saran dari pembimbing dan pihak lainnya. Oleh karena itu pada kesempatan ini penulis menyampaikan terimakasih sebesar-besarnya kepada Prof. Dr. I Nyoman Darma Putra, M.Litt selaku Pembimbing I dan Dr. Ir. I Made Adhika, MSP selaku Pembimbing II, yang dengan kesabaran memberikan bimbingan, masukan, dan saran untuk kesempurnaan tesis ini. Ucapan terimakasih disampaikan kepada para penguji yaitu Dr. Ir. Syamsul Alam Paturusi, MSP, Dr. Ida Bagus Gde Pujaastawa, MA dan Dr. Dewa Putu Oka Prasiasa, A.Par., MM yang telah banyak memberikan masukan, kritik dan saran serta koreksi demi kesempurnaan penulisan tesis.

\section{Daftar Pustaka}

Arifin, Zainal. 2012. Evaluasi Pembelajaran. Jakarta: Kementerian Agama RI.

Nurjanah, Riani. 2012. "Studi Persepsi Dampak Perubahan Pemanfaatan Lahan Terhadap Kunjungan Wisata di Pulau Pramuka Kepulauan Seribu”. Jurnal Perencanaan Wilayah dan Kota. Vol. 23 No. 2, Hal. 139-156. Sumber: URL: http://www.sappk.itb.ac.id/jpwk/?page_id=1180 diakses 20 Juni 2015.

Pitana, I Gde dan Putu G. Gayatri. 2005. Sosiologi Pariwisata. Yogyakarta: Andi.

Sugiyono. 2014. Metode Penelitian Kuantitatif dan Kualitatif dan R \& D. Bandung: Alfabeta.

Sunaryo, Bambang. 2013. Kebijakan Pembangunan Destinasi Pariwisata, Konsep dan Aplikasinya di Indonesia. Yogyakarta: Gava Media.

Zhang, G. et. al. 2011. "Using the Context, Input, Process, and Product Evaluation Model (CIPP) as a Comprehensive Framework to Guide the Planning, Implementation, and Assessment of Service-learning Programs”. Jurnal of Higher Education Outreach and Engagement. Volume 15, Number 4, p.57. Georgia: University of Georgia. 


\section{Profil Penulis}

I Made Agus Asta Panca adalah Pegawai Negeri Sipil (PNS) yang bekerja di Badan Kepegawaian Daerah Provinsi Bali. Ia menyelesaikan program studi D-IV di Sekolah Tinggi Pemerintahan Dalam Negeri (STPDN) pada tahun 2007 dan program Magister Pariwisata di Universitas Udayana pada tahun 2015.

I Nyoman Darma Putra adalah Ketua Prodi Magister Kajian Pariwisata Pascasarjana Universitas Udayana. Minat penelitiannya meliputi sastra, budaya, dan pariwisata. Tahun 2007, bersama Michael Hitchcock, Darma menulis buku Tourism Development and Terrorism in Bali (Ashgate, 2007). Email: idarmaputra@yahoo.com 